\title{
Identification of a potential physiological precursor of aberrant cells in refractory coeliac disease type II
}

\author{
Frederike Schmitz, ${ }^{1}$ Jennifer M L Tjon, ${ }^{1}$ Yuching Lai, ${ }^{2,3}$ Allan Thompson, ${ }^{1}$ \\ Yvonne Kooy-Winkelaar, ${ }^{1}$ Richard J L F Lemmers, ${ }^{2}$ Hein W Verspaget, ${ }^{4}$ \\ M Luisa Mearin, ${ }^{5}$ Frank J Staal, ${ }^{1}$ Marco W Schreurs, ${ }^{6}$ Tom Cupedo, \\ Anton W Langerak, ${ }^{6}$ Chris J Mulder, ${ }^{8}$ Jeroen van Bergen, ${ }^{1}$ Frits Koning ${ }^{1}$
}

- Additional figure and table are published online only. To view these files please visit the journal online (http://dx.doi.org/ 10.1136/gutjnl-2012-302265).

'Department of

Immunohematology and Blood Transfusion, Leiden University Medical Center, Leiden, The Netherlands

${ }^{2}$ Department of Human and Clinical Genetics, Leiden University Medical Center Leiden, The Netherlands ${ }^{3}$ Leiden Genome Technology

Center, Leiden, The Netherlands

${ }^{4}$ Department of

Gastroenterology and

Hepatology, University Medical

Center, Leiden, The Netherlands

${ }^{5}$ Department of Pediatrics,

Leiden University Medical

Center, Leiden, The Netherlands

${ }^{6}$ Department of Immunology,

Erasmus University Medical

Center, Rotterdam, The

Netherlands

${ }^{7}$ Department of Hematology,

Erasmus University Medical

Center, Rotterdam, The

Netherlands

${ }^{8}$ Department of

Gastroenterology, VU Medical

Center, Amsterdam, The

Netherlands

\section{Correspondence to}

Dr Frits Koning, Department of Immunohematology, Leiden

University Medical Center,

Albinusdreef 2, 2333 ZA Leiden,

The Netherlands;

f.koning@lumc.n|

FS and JMLT contributed equally to this manuscript, as did senior authors JvB and FK.

Revised 24 May 2012

Accepted 30 May 2012

Published Online First

6 July 2012

\section{SLinked}

http://dx.doi.org/10.1136/ gutjnl-2012-303030

\section{ABSTRACT}

Objective Refractory coeliac disease type II (RCDII) is a severe complication of coeliac disease (CD) characterised by aberrant intraepithelial lymphocytes (IELs) of unknown origin that display an atypical $\mathrm{CD}^{-} \mathrm{CD}^{+}{ }^{+} \mathrm{iCD}^{+}$phenotype. In approximately $40 \%$ of patients with RCDII these lymphocytes develop into an invasive lymphoma. In the current study we aimed to identify the physiological counterpart of these cells. Design RCDIl cell lines were compared with T-cell receptor positive $\left(\mathrm{TCR}^{+}\right.$) IEL (T-IEL) lines by microarray analysis, real-time quantitative PCR and flow cytometry. This information was used to identify cells with an RCDIIassociated phenotype in duodenal biopsies from nonrefractory individuals by multicolour flow cytometry. Results RCDII lines were transcriptionally distinct from T-IEL lines and expressed higher levels of multiple natural killer (NK) cell receptors. In addition to the $\mathrm{CD}^{-} \mathrm{CD}^{+}{ }^{+} \mathrm{iCD}^{+}$phenotype, the RCDII lines were distinguishable from other lymphocyte subsets by the absence of CD56, CD127 and CD34. Cells matching this surface lineage-negative $\left(\mathrm{Lin}^{-}\right) \mathrm{CD} 7^{+} \mathrm{CD} 127^{-} \mathrm{CD} 34$ phenotype expressed a functional interleukin-15 (IL-15) receptor and constituted a significant proportion of IELS in duodenal specimens of patients without $C D$, particularly children, and were also found in the thymus. In patients without $\mathrm{CD}$, the $\mathrm{Lin}^{-} \mathrm{CD} 7^{+} \mathrm{CD} 127^{-} \mathrm{CD} 34^{-}$ subset was one of four subsets within the $\mathrm{CD}^{-} \mathrm{CD}^{+}{ }^{+} \mathrm{CCD}^{+}$population that could be distinguished on the basis of differential expression of CD56 and/or CD127.

Conclusion Our studies indicate that the $\mathrm{CD}^{-} \mathrm{CD}^{+}{ }^{+} \mathrm{CCD}^{+}$population is heterogeneous and reveal the existence of a $\mathrm{Lin}^{-}$subset that is distinct from T, B, NK and lymphoid tissue inducer cells. We speculate that this IL-15 responsive population represents the physiological counterpart of aberrant cells expanded in RCDII and transformed in RCDII-associated lymphoma.

\section{INTRODUCTION}

Coeliac disease (CD) is an enteropathy of the small intestine induced in $\mathrm{HLA}^{-\mathrm{DO}} 2^{+}$and/or HLA$\mathrm{DQ} 8^{+}$individuals by a polyclonal $\mathrm{CD} 4^{+} \mathrm{T}$-cell response to gluten, leading to villous atrophy and crypt hyperplasia. ${ }^{1}$ In addition, the number of T-cell receptor (TCR)- $\alpha \beta^{+}$and TCR- $\gamma \delta^{+}$intraepithelial lymphocytes (IELs) is strongly increased ${ }^{2}$ and interleukin 15 (IL-15) is highly upregulated in the epithelium and in the lamina propria. ${ }^{3} 4$

\section{Significance of this study}

What is already known about this subject?

- Refractory coeliac disease (RCD) is characterised by persistent pathology despite a glutenfree diet.

- RCD is subdivided into two types; RCDII presents with a monoclonal expansion of aberrant $\mathrm{CD}^{-} \mathrm{CD}^{+}{ }^{+} \mathrm{icCD}^{+}$intraepithelial lymphocytes (IELs), constituting over $20 \%$ of the IEL population and potentially transforming into an invasive lymphoma (enteropathyassociated T cell lymphoma).

- Knowledge about the non-T-cell population in the healthy intestine is sparse: $\mathrm{CD}^{-} \mathrm{CD}^{+}$were shown to contain natural killer (NK) and pre $T$ cells and were found to be reduced in patients with CD compared with those without

- Interleukin-15 (IL-15) is upregulated in the duodenum of patients with RCDII and stimulates the survival and expansion of aberrant IELs.

What are the new findings?

- Compared with $\mathrm{TCR}^{+} \mathrm{CD}^{+}$IEL (T-IEL) from patients with $C D$, aberrant IEL lines from those with RCDII overexpressed NK-cell associated genes; the RCDII cell lines were lineage-negative $\left(\mathrm{Lin}^{-}\right), \quad \mathrm{CD} 7^{+} \mathrm{CD} 127^{-} \mathrm{CD} 34^{-}$, distinguishing them from other intestinal lymphocyte populations.

- In children without $\mathrm{CD} \mathrm{Lin}^{-} \mathrm{CD} 7^{+} \mathrm{CD} 127^{-} \mathrm{CD} 34^{-}$ IEL constituted up to $30 \%$ of the IEL population of which up to $40 \%$ were ic $\mathrm{CD}^{+}$, displayed high expression of the IL-15R $\beta$ chain (CD122) and proliferated in response to IL-15.

- In patients without celiac disease, this $\mathrm{Lin}^{-} \mathrm{CD} 7^{+} \mathrm{CD} 127^{-} \mathrm{CD} 34^{-}$population was one of four subsets present in the duodenal $\mathrm{CD}^{-} \mathrm{CD}^{+}{ }^{+} \mathrm{iCD}^{+}$population.

Elimination of gluten from the diet usually restores the intestinal architecture, accompanied by a reduction in TCR- $\alpha \beta^{+}$IELs but not TCR- $\gamma \delta^{+}$IELs. However, $2-5 \%$ of patients with adult-onset CD develop refractory CD (RCD) with persisting epithelial damage and increased numbers of IELs, despite strict adherence to a gluten-free diet. 


\section{Significance of this study}

\section{How might it impact on clinical practice in the foreseeable} future?

- Due to the low numbers of patients and the complicated pathology of RCD, the development of optimal diagnosis and treatment methods has remained a challenge. The addition of CD56, CD34 and CD127 to the current marker sets used for diagnosis of RCDII will help classify the expanded IEL population and may ultimately be linked to differential prognoses and responsiveness to treatment. Identification of the physiological cell population from which the aberrant IEL and lymphoma cells derive may help us understand what causes the resistance to a gluten-free diet and drives the expansion of these cells in RCDII and enteropathyassociated T-cell lymphoma and thus provide clues to its treatment.

Based on immunophenotyping of the IEL population, RCD is subdivided into two types: RCD type I (RCDI) and RCD type II (RCDII). RCDI presents with $<20 \%$ aberrant IELs, whereas in RCDII $>20 \%$ of the IELs have an aberrant phenotype. ${ }^{6}$ For diagnostic purposes, aberrant IELs are defined as surface $\mathrm{TCR}^{-} \mathrm{CD}^{-} \mathrm{CD}^{-} \mathrm{CD}^{-} \mathrm{CD}^{+}$but intracellular $\mathrm{CD}^{+}$cells that commonly display monoclonal TCR- $\gamma$ gene rearrangements. ${ }^{67}$ In RCDII, the aberrant IELs gradually replace the normal IEL population and can undergo malignant transformation into lymphoma. ${ }^{8}$

The cellular origin of the aberrant $\mathrm{CD}^{-} \mathrm{CD}^{+}{ }^{+} \mathrm{CCD} 3^{+}$ population that expands in RCDII is still unclear. One view is that aberrant IELs originate from mature $\mathrm{TCR}^{+} \mathrm{CD}^{+}$IELs (T-IEL) that downregulate the TCR-CD3 complex due to overstimulation. ${ }^{7}$ This view is supported by the observation that aberrant IELs have intracellular expression of the CD3 $\gamma$, $\mathrm{CD} 3 \delta, \mathrm{CD} 3 \varepsilon$ and $\zeta$ chains and commonly display monoclonal TCR- $\gamma$ gene rearrangements. ${ }^{7-9}$ Intracellular CD3 expression, however, is not exclusive to mature $\mathrm{T}$ cells as pre $\mathrm{T}$ cells and some natural killer (NK) cells also express all CD3 chains intracellularly. ${ }^{10} 11$ Therefore, an alternative view is that aberrant IELs derive from a surface $\mathrm{CD}^{-} \mathrm{CD}^{+}$IEL population that is already present in the healthy small intestine. By immunohistochemical analysis ${ }^{12}$ and three-colour flow cytometry ${ }^{13}$ the $\mathrm{CD}^{-} \mathrm{CD}^{+}$IEL population was studied in patients with $\mathrm{CD}$ and those without, demonstrating a reduction of this population in patients with CD compared with those without. Later studies focused on the composition and characterisation of this IEL population in the intestine of people without $\mathrm{CD} .^{12}{ }^{14-18}$ The $\mathrm{CD}^{-} \mathrm{CD}^{+}$IEL population proved to contain NK cells ${ }^{17}$ and immature T cells. ${ }^{14-16}{ }^{18}$ Due to limitations of the techniques applied and the small amount of cells available from biopsy material an accurate identification and quantification of rare (sub)populations within the IEL population is challenging. In the present study we therefore combined microarray analysis, real-time quantitative PCR (RT-qPCR) and multicolour flow cytometry to extensively characterise aberrant RCDII cell lines from patients with RCDII. Subsequently, we used this information to design a multicolour staining protocol to investigate the presence and phenotype of RCDII-like cells in duodenal biopsy material from patients with $\mathrm{CD}$ and those without as a first step to determine the cellular origin of aberrant IELs.

\section{MATERIALS AND METHODS} Human specimens

Duodenal biopsies were obtained as previously described. ${ }^{9}$ Fetal tissues were obtained from elective abortions and gestational age was determined by ultrasonic measurement of the diameter of the skull or the femur. Thymic material was obtained as surgical tissue discards from four children without immunological abnormalities (2, 5, 7 and 8 months old) undergoing cardiac surgery. Thymocytes were isolated as described ${ }^{19}$ and stored at $-80^{\circ} \mathrm{C}$ until further analysis.

All specimens were obtained after informed consent, medical ethical commission approval and in accordance with the local ethical guidelines of the VU Medical Center in Amsterdam (adult duodenal biopsies), the Leiden University Medical Center (paediatric duodenal biopsies) or the Erasmus MC in Rotterdam (fetal intestine, thymuses) and in accordance with the declaration of Helsinki.

\section{Cell lines and cell culture}

RCDII cell lines P1, P2, P3 and P4 were isolated from duodenal biopsies of patients with RCDII and maintained as described. ${ }^{9}$ Control cell lines for P1 were a CD4 ${ }^{+} \mathrm{T}$-cell line (P1-CD4) and a $\mathrm{CD}^{+} \mathrm{T}$-cell line (P1-CD8) isolated from the same biopsy as the RCDII cell line P1. A CD4 ${ }^{+}$T-cell clone (P3-CD4) and a $\mathrm{CD} 8^{+} \mathrm{T}$-cell line (P1-CD8) was isolated from the same biopsy as the RCDII cell line $\mathrm{P} 1$ or $\mathrm{P} 3$, respectively. T-IEL lines $\left(\mathrm{CD} 4^{+}\right.$ and $\mathrm{CD} 8^{+} \mathrm{T}$ : IEL1-5) were isolated from four patients with $\mathrm{CD}$ and one patient with Crohn's disease, as described for RCDII lines. IEL1-CD4 was derived from IEL1, IEL5-CD8 from IEL5. NK cells were negatively selected from peripheral blood mononuclear cells (PBMCs) by depletion using MACS beads (Miltenyi, Bergisch Gladbach, Germany).

RCDII lines and T cells were restimulated with mixed irradiated allogeneic PBMCs, $1 \mu \mathrm{g} / \mathrm{ml}$ phytohaemagglutinin, 20 Cetus units/ml interleukin (IL)-2 (Proleukin, Chiron corporation, Emeryville, California, USA) and $10 \mathrm{ng} / \mathrm{ml}$ IL-15 (R\&D systems Europe, Abingdon, UK) approximately every 4 or 2 weeks, respectively and maintained on $10 \%$ normal human serum (NHS) containing $10 \mathrm{ng} / \mathrm{ml}$ IL-15 and 20 Cetus units/ml IL-2. After isolation, NK cells were cultured for 2 weeks in AMV-I medium containing $10 \% \mathrm{NHS}$ and IL-15 $(10 \mathrm{ng} / \mathrm{ml})$.

\section{Isolation of cells from duodenal biopsy specimen for flow cytometry}

Cells were isolated from two or three duodenal biopsies by treatment with $1 \mathrm{mM}$ DTT (Fluka, Buchs, Switzerland) for 20 min followed by the addition of 1 mM EDTA (Merck, Darmstadt, Germany) under rotation for $2 \mathrm{~h}$ at $37^{\circ} \mathrm{C}$. Since DTT incubation decreases CD103 expression ${ }^{20}$ all $\mathrm{CD} 45^{+}$cells were considered IELs. The IELs were then washed with phosphatebuffered saline (PBS) containing $0.5 \%$ fetal calf serum (FCS) and fixed for $10 \mathrm{~min}$ at $4^{\circ} \mathrm{C}$ with $\mathrm{PBS}$ containing $0.1 \%$ paraformaldehyde and $0.5 \%$ FCS. After washing the cells were kept at $4^{\circ} \mathrm{C}$ until flow cytometric analysis.

\section{Antibodies and flow cytometry}

Fluorochrome-labelled antibodies specific for CD1a, CD2, CD3, CD4, CD5, CD6, CD7, CD8 $\alpha$, CD11a, CD16, CD18, CD25, CD27, CD28, CD30, CD31, CD33, CD34, CD38, CD40, CD44, CD45RA, CD45RO, CD54, CD56, CD62L, CD94, CD103, CD117, CD122, CD152, CD154, CD161, CD226, integrin $\beta 7$, killer-cell immunoglobulin-like receptor (KIR)-3DL1 and NKG2D were purchased from BD Biosciences (San Jose, California, USA). Fluorochrome-labelled antibodies specific for CD8 $\beta$, KIR2DL2/ 
DL3/DS2, KIR2DL1/2DS1, KIR2DS4, KIR3DL1, CD244, NKp30, NKp44 and NKp46 were purchased from Beckman Coulter (Fullerton, California, USA). Fluorochrome-labelled antibodies specific for IL-15R $\alpha$, KIR2DL3, KIR2DL4, NKG2A and NKG2C were purchased from R\&D systems. Anti-CD19 was from Exbio (Vestec, Czech Republic), anti-CD14 from Immunotools (Friesoythe, Germany), anti-CD7, CD127, CD45 and Ki-67 were from eBioscience (San Diego, California, USA) and anti-CD52 was from Genzyme (Cambridge, UK). The anti-KIR2DS2/2DL3 antibody was a kind gift from Dr C Retiere, ${ }^{21}$ the anti-KIR3DL2 antibody from Dr D Pende ${ }^{22}$ and the anti-KIRDL5 antibody from Dr C Vilches. ${ }^{23}$ For antibody clone names see table 1.

For surface staining, cells were incubated for $30 \mathrm{~min}$ with fluorochrome-conjugated antibodies. For intracellular CD3 or Ki67 staining, the cells were subsequently lysed with BD lysing solution for $10 \mathrm{~min}$ at room temperature then washed thoroughly and treated with permeabilising solution 2 (BD) for $10 \mathrm{~min}$ at room temperature, after which the cells were incubated with

Table 1 Flow cytometry analysis of refractory coeliac disease type II cell lines P1-P4

\begin{tabular}{|c|c|c|c|c|c|c|}
\hline Cell Type & Marker & Antibody clone name & P1 & $\mathbf{P 2}$ & P3 & P4 \\
\hline Leucocyte & CD11a & G43-25B & & & & \\
\hline Leucocyte & CD18 & L130 & & & & \\
\hline Leucocyte & CD54 & LB-2 & & & & \\
\hline Leucocyte & CD62L & SK11-EMPTY & & & & \\
\hline Leucocyte & CD31 & WM59 & & & & \\
\hline Leucocyte & CD52 & Campath 1-H & & & & \\
\hline Leucocyte & CD45 & 2D1 & & & & \\
\hline Monocyte & CD14 & MEM-15 & & & & \\
\hline Monocyte & CD33 & HIM3-4 & & & & \\
\hline B (pre-B) & CD10 & ALB2 & & & & \\
\hline B & CD40 & $5 \mathrm{C} 3$ & & & & \\
\hline B & CD19 & LT19 & & & & \\
\hline$T / B$ & CD6 & MT605 & & & & \\
\hline$T / B$ & CD5 & L17F12 & & & & \\
\hline T/B/NK & CD38 & $\mathrm{HB} 7$ & & & & \\
\hline T/B/NK & CD30 & BerH8 & & & & \\
\hline T/B/NK & CD45 RA & L48 & & & & \\
\hline$T$ & CD3 & S4.1 & & & & \\
\hline T/NK & CD3 ic & SK7 & & & & \\
\hline$T$ & CD4 & SK3 & & & & \\
\hline T/NK & CD8- $\alpha$ & SK1 & & & & \\
\hline$T$ & $C D 8-\beta$ & $2 \mathrm{ST} 8.5 \mathrm{H} 7$ & & & & \\
\hline$T$ & CD45 RO & $\mathrm{UCHL} 1$ & & & & \\
\hline $\mathrm{T}$ & CD152 & BN13 & & & & \\
\hline$T$ & CD154 & TRAP1 & & & & \\
\hline$T$ & CD44 & G44-26 & & & & \\
\hline$T$ & $\mathrm{CD} 28$ & CD28.2 & & & & \\
\hline T/LTI & CD127 & ebioRDR5 & & & & $40 \%$. \\
\hline T/NK & $\mathrm{CD} 2$ & S5.2 & & & & \\
\hline T/NK & CD25 & M-A251 & & & & \\
\hline T/NK & CD27 & M-T271 & & & & \\
\hline T/NK & $\mathrm{CD} 7$ & $6 \mathrm{~B} 7$ & & & & \\
\hline T/NK & Integrin beta-7 & F1B504 & & & & \\
\hline IEL T/NK & CD103 & Ber-ACT8 & & & & \\
\hline $\mathrm{NK} / \mathrm{T}$ & CD122 & TU27 & & & & \\
\hline $\mathrm{NK} / \mathrm{T}$ & IL15 Ra & 151303. & & & & \\
\hline $\mathrm{NK} / \mathrm{T}$ & CD56 & MEM-188 & & & $2 \%$. & \\
\hline $\mathrm{NK} / \mathrm{T}$ & CD161 & DX12 & & & & \\
\hline $\mathrm{NK} / \mathrm{T}$ & CD16 & GO22 & & & & \\
\hline $\mathrm{NK} / \mathrm{T}$ & CD226 & DX11 & & & & \\
\hline $\mathrm{NK} / \mathrm{T}$ & KIR2DL1/S1 & EB6 & & & & \\
\hline $\mathrm{NK} / \mathrm{T}$ & KIR2DL2/L3/S2 & GL183 & & & & \\
\hline $\mathrm{NK} / \mathrm{T}$ & KIR2DL4 & 181703. & & & & \\
\hline $\mathrm{NK} / \mathrm{T}$ & KIR2DL5 & UP-R1 & & & & \\
\hline $\mathrm{NK} / \mathrm{T}$ & KIR2DS2/L3 & $1 \mathrm{~F} 12$ & & & & \\
\hline $\mathrm{NK} / \mathrm{T}$ & KIR2DS4 & FES172 & & & & \\
\hline $\mathrm{NK} / \mathrm{T}$ & KIR3DL1 & DX9 & & & & \\
\hline $\mathrm{NK} / \mathrm{T}$ & KIR3DL2 & Q66 & & & & \\
\hline $\mathrm{NK} / \mathrm{T}$ & CD94 & HP-3D9 & & & & \\
\hline $\mathrm{NK} / \mathrm{T}$ & NKG2A & 131411. & & & & \\
\hline $\mathrm{NK} / \mathrm{T}$ & NKG2C & 134591. & & & & \\
\hline $\mathrm{NK} / \mathrm{T}$ & NKG2D & 149810. & & & & \\
\hline $\mathrm{NK} / \mathrm{T}$ & CD244 (2B4) & C1.7 & & & & \\
\hline $\mathrm{NK} / \mathrm{T}$ & NKp30 & 210845. & & & & \\
\hline $\mathrm{NK} / \mathrm{T}$ & NKp44 & 253415. & & & & \\
\hline $\mathrm{NK} / \mathrm{T}$ & NKp46 & 195314. & & & & \\
\hline $\mathrm{NK} / \mathrm{T}$ & NKp80 & 4A4.D10 & & & & \\
\hline pre T/NK & CD1a & HI149 & & & & \\
\hline pre T/NK & CD117 & 104D2 & & & & \\
\hline lymphoid precursor & CD34 & $8 \mathrm{G} 12$ & & & & \\
\hline
\end{tabular}

White: no expression of the marker; Black: uniform expression of the marker;

Gray: partial expression of the marker, percentage positive cells is indicated. CD3ic $=$ intracellular CD3 
anti-CD3 or anti-Ki-67 for an additional $30 \mathrm{~min}$ and washed again. Antibody-stained cells were acquired on an LSR II or FACSCalibur (BD Biosciences) and the results were analysed with FACSDIVA V.6.1.2 or FlowJo V.7.6.3 software. Relative mean fluorescence intensity (MFI) was calculated as follows: (MFI staining antibody)/(MFI isotype control). Percentages obtained from FACS analysis were computed in 4-GraphPad.

\section{RNA isolation and preparation}

Total RNA was extracted from cell lines using the RNeasy Mini Kit (Qiagen, Venlo, the Netherlands) followed by DNAse digestion using the RNase-free DNAse kit (Qiagen). The RNA samples were labelled in duplicate with the Ambion Illumina TotalPrep RNA-amplification kit (Illumina, Son, The Netherlands) for the microarray study.

\section{Microarray hybridisation and microarray data analysis}

Biotinylated cRNA samples were hybridised on 2 Illumina HumanHT-12 V3 Expression BeadChips according to the Illumina BeadArray protocol. Samples were randomly distributed among the two BeadChips.

The intensities of the expression results were parsed into the $\mathrm{R}$ statistical computing environment using the beadarray package. ${ }^{24}$ Gene expression values were $\log _{2}$ transformed and normalised using the quantile method across all samples. Samples were grouped into lymphoma and control for a twosample comparative study, fold changes and adjusted $p$ values were calculated using the limma package. ${ }^{25}$ The Benjamini and Hochberg method was used to adjust $p$ values for multipletesting errors. The cut-off criteria for differential expression was set at a relative difference of more than sevenfold change and adjusted $\mathrm{p}$ value $<0.001$

Unsupervised hierarchical clustering of the samples was done using the complete clustering method with the Euclidean distance metric. The result was plotted using the heatmap. 2 function from the $\mathrm{R}$ plots package. Gene ontology clusters were determined with PANTHER (http://www.pantherdb.org/).

\section{Real-time quantitative PCR}

cDNA was synthesised using superscript reverse transcriptase III (Invitrogen, Grand Island, New York, USA), following the manufacturer's instructions. Gene-specific PCR primers were designed using the Roche web-based universal ProbeFinder software tool, V.2.45 (www.roche-applied-science.com). RTqPCR was performed in a Step One Plus Real Time PCR System (Applied Biosystems, Carlsbad, California, USA). The reactions were set up in a Microamp 96 well plate (Applied Biosystems), using the forward and reverse primers (each at $400 \mathrm{nM}$ ) in Fast Start Universal SYBR Green Master Mix solution (Roche, Germany). The thermal profile for all reactions was $10 \mathrm{~min}$ at $95^{\circ} \mathrm{C}$, followed by 40 cycles of $15 \mathrm{~s}$ at $95^{\circ} \mathrm{C}$ and $1 \mathrm{~min}$ at $60^{\circ} \mathrm{C}$. All RT-qPCR measurements were done in triplicate. The $\Delta$ threshold cycle (CT) values were determined using GAPDH as the reference gene.

\section{Statistics}

Statistical analysis was conducted using two-tailed unpaired Student $t$ test. A p value $<0.05$ was considered significant.

\section{RESULTS}

Molecular analysis reveals higher expression levels of NK cellassociated genes on RCDII lines compared with TCR ${ }^{+}$IEL lines To define the differences between aberrant IELs and regular T-IELs in detail, aberrant cell lines from patients with RCDII (RCDII lines) and control T-IEL cell lines were subjected to microarray analysis. The RCDII cell lines were isolated from small intestinal biopsies of patients with RCDII (P1, P2 and P3) and displayed the characteristic phenotype of aberrant IELs: surface $\mathrm{TCR}^{-}, \mathrm{CD}^{-}$, $\mathrm{CD}^{-}, \mathrm{CD}^{-}, \mathrm{CD}^{+}, \mathrm{CD} 103^{+}$, intracellular $\mathrm{CD}^{+}{ }^{9}{ }^{9}$ The controls included five polyclonal $\mathrm{CD}_{103^{+}} \mathrm{CD}^{+}$and $\mathrm{CD}^{+}{ }^{+} \mathrm{TCR} \alpha \beta^{+}$ T-IEL lines (T-IEL); a $\mathrm{CD}^{+}{ }^{+} \mathrm{TCR}^{+}$cell line from patient $\mathrm{P} 1$ (P1-CD4); a CD4 ${ }^{+} \mathrm{TCR}^{+}$clone from patient P3 (P3-CD4); and a $\mathrm{CD}^{+} \mathrm{TCR}^{+}$IEL line from patient P1 (P1-CD8).

Unsupervised hierarchical clustering analysis revealed two main branches: one contained the RCDII lines while the other contained all control $\mathrm{TCR}^{+}$cell lines, including those from patients P1 and P3 (figure 1A). Therefore, the RCDII lines were transcriptionally distinct from $\mathrm{TCR}^{+}$cell lines, yet similar to each other. The RCDII lines had relatively high expression values of NK-cell-associated genes. The amount of KIR transcripts was roughly 5 -fold to 20 -fold higher in RCDII lines versus controls. Furthermore, the RCDII lines showed higher expression levels of phospholipase C $\gamma 2$ (PLCG2), which plays a pivotal role in secretion of cytotoxic granules in NK cells. ${ }^{26}$ The RCDII lines also had higher expression levels of $\mathrm{SH} 2$ domain containing $1 \mathrm{~B}$ (SH2D1B/EAT-2) which can act as an adapter molecule for the cell surface receptors CD84, CD244 and CD150 (SLAMF1). ${ }^{27}$ All RCDII cell lines expressed CD244 (table 1), a receptor expressed by NK cells and effector/memory $\mathrm{T}$ cells, ${ }^{28}$ while SLAMF1 expression was downregulated in the RCDII cell lines. In addition, several other genes that are associated with T-cell mediated immunity according to the PANTHER classification were downregulated in the RCDII lines compared with the T-cell lines, in particular granulysin (GNLY), lymphotoxin $\beta$ (LTB) and tumour necrosis factor receptor 4 (figure $1 \mathrm{~A}, \mathrm{~B}$ ). The differential expression of seven genes (TNS3, SLAMF1, FoxD1, SH2D1B, PLCG2, LAT, LTB) was confirmed by RT-qPCR (figure $1 B$ and data not shown). An additional 12 surface markers (CD154, CD278, CD6, CD44, CD7, CD244, CD82, CD160, CD127, CD18, CD5, CD158d) were analysed by flow cytometry (figure 2 and data not shown) and also corroborated the microarray results. Furthermore, analysis of TCR rearrangements revealed that none of the RCDII lines possessed functionally rearranged TCR $\alpha / \beta$ or TCR $\gamma / \delta$ loci. ${ }^{29}$ Together, these data showed that RCDII lines were distinct from mature T-cell lines and expressed several NK-cell-associated genes.

\section{RCDII lines display a previously undescribed lymphocyte phenotype}

To confirm and extend the results of the microarray analysis, we determined the expression of a large set of cell surface markers on RCDII lines $\mathrm{P} 1, \mathrm{P} 2, \mathrm{P}^{9}$ and on RCDII line P4 by flow cytometry (table 1). RCDII line P4 (online supplementary figure 1) was derived from an additional patient with RCDII. Like TIEL, all RCDII lines expressed the pan-leucocyte marker CD45 but lacked expression of B-cell marker CD19 and monocyte marker CD14 (table 1). Although the RCDII lines did not express the NK cell marker CD56 (with the exception of a small $\mathrm{CD}^{+} 6^{+}$fraction within RCDII line P3, see table 1), they each expressed a unique selection of NK cell receptors (table 1). Consistent with the microarray results (figure 1A), all RCDII lines but not the control T-cell lines expressed KIR2DL4/ CD158d (figure 2A), which has thus far been detected on mature $\mathrm{NK}$ cells and memory $\mathrm{T}$ cells only. In addition, these cells expressed the IL-2/15R $\beta$ chain (CD122), normally found on NK cells and memory $\mathrm{T}$ cells (table 1 ). These results confirm and extend previous studies ${ }^{30-32}$ and indicate that RCDII lines share features with T and NK cells. 
Figure 1 RCDII lines express higher levels of natural killer (NK) cellassociated genes compared with regular $\mathrm{TCR}^{+}$cell lines (T-IEL). (A) Unsupervised hierarchical clustering analysis of the gene expression profiles of RCDIl lines P1, P2 and P3 and TCR ${ }^{+}$ cell lines P1-CD4, P1-CD8, P3-CD4 and IEL1-5. The heat map depicts the log intensity values of differentially expressed genes with a false discovery rate of $p<0.01$ and a fold change difference of more than seven. Darker grey corresponds to higher log intensity values. KIR allocation was imprecise as KIR probes anneal to transcripts of multiple KIR genes. (B) Quantification of differential gene expression by real-time quantitative PCR. Relative expression of SH2D1B, PLCG2, LAT and LTB in RCDII lines (P1-P4), T-IEL lines (IEL1-4) and $\mathrm{CD}^{+}{ }^{+}$T-cell lines (CD4T: P1-CD4, P3CD4, IEL1-CD4), CD8 ${ }^{+}$T-cell lines (CD8T: P1-CD8, P3-CD8, IEL5-CD8) and NK cell lines from four independent donors (NK cells). The $\Delta$ CT value is depicted on the $y$-axis. IEL, intraepithelial lymphocyte; NK, natural killer; CT, threshold cycle; RCDII, refractory coeliac disease type II; T-IEL, T-cell receptor positive intraepithelial lymphocyte.

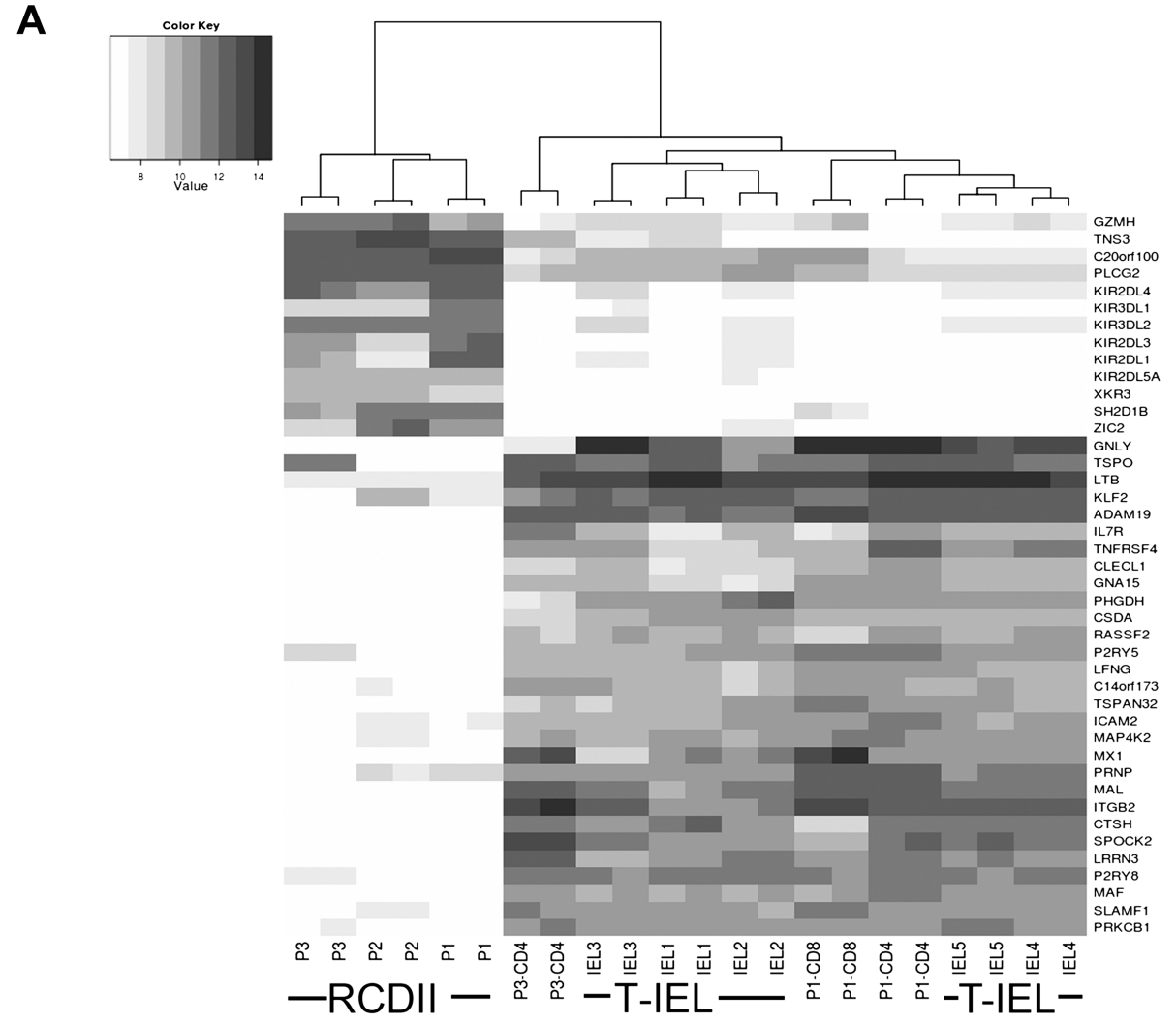

B

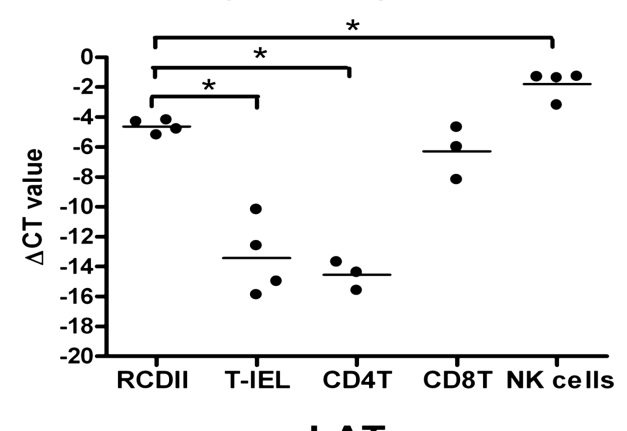

SH2D1B/EAT2

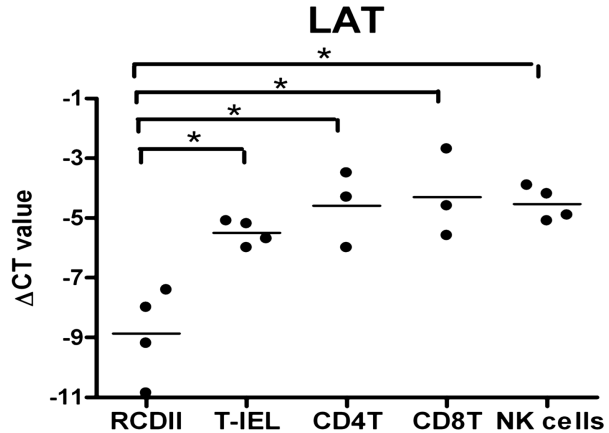

PLCG2
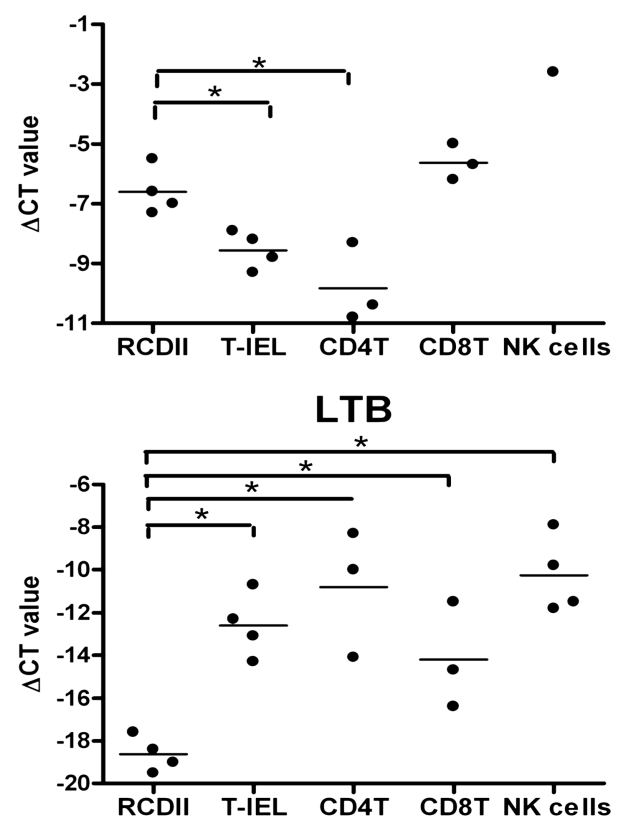

The absence of the main lineage (Lin) markers (CD3, CD14, CD19, CD56) in combination with intracellular CD3 would be consistent with an immature lymphocyte phenotype. However, the RCDII lines did not express CD34, CD1a or CD117 (table 1), markers associated with T-cell and NK-cell precursors. ${ }^{33} 34$ Furthermore, RCDII lines P1, P2, P3 did not express RAR-related orphan receptor $\mathrm{C}$ (RORC) transcripts (data not shown) or the CD127/IL-7 receptor on the cell surface (table 1, figure 2D). RCDII line P4 was partly CD127 (IL-7R $\alpha$ ) positive, but ROR-C negative (data not shown). Therefore, the RCDII lines also did not match the phenotype of lymphoid tissue inducer cells (LTi) cells, a Lin ${ }^{-}$ $\mathrm{CD}_{12} 7^{+} \mathrm{RORC}^{+}$cell population present in the small intestine. ${ }^{3536}$

Together, these results demonstrate that the RCDII lines share features with $\mathrm{T}$ and NK cells and display a previously undescribed IEL phenotype: $\mathrm{Lin}^{-} \mathrm{CD} 7^{+} \mathrm{CD} 127^{-} \mathrm{CD} 34^{-}$.

\section{$\mathrm{Lin}^{-} \mathrm{CD7}^{+} \mathrm{CD}^{-127^{-} \mathrm{CD}^{-}}{ }^{-}$IELs are also found in people without CD}

Next we investigated if cells with a $\mathrm{Lin}^{-} \mathrm{CD} 7^{+} \mathrm{CD} 127^{-} \mathrm{CD} 34^{-}$ phenotype were also present in people without CD. Multicolour 
Figure 2 Confirmation of differentially expressed genes from figure 1 by flow cytometry analysis. RCDII lines (P1-P4) and T-IEL (IEL1-5, IEL1-CD4, P1-CD8, P3-CD8, IEL5-CD8) were analysed for expression of (A) CD158d (KIR2DL4), (B) CD5, (C) CD18 (ITGB2) and (D) CD127 (IL7R) by flow cytometry. On the left, a histogram of a representative staining for one RCDII and one T-IEL line (grey filling = isotype, no filling = antibody) is shown. The scatter plots on the right depict the relative mean fluorescence intensities (relative MFI = MFI antibody/MFI isotype) of all RCDII and T-IEL lines. ${ }^{*} \mathrm{p}<0.05$. KIR, killer-cell immunoglobulin-like receptor; ITGB2, integrin beta 2; IL7RA, interleukin 7 receptor alpha; MFI, mean fluorescence intensity; RCDIl, refractory coeliac disease type II; T-IEL, T-cell receptor positive intraepithelial lymphocyte.
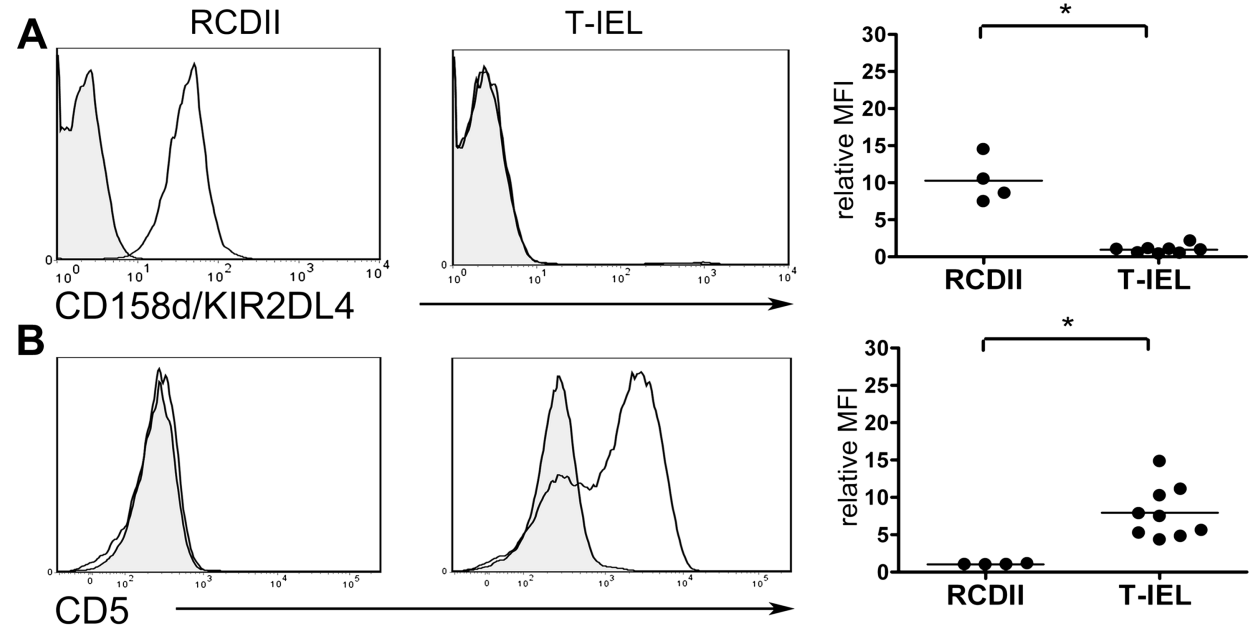

C

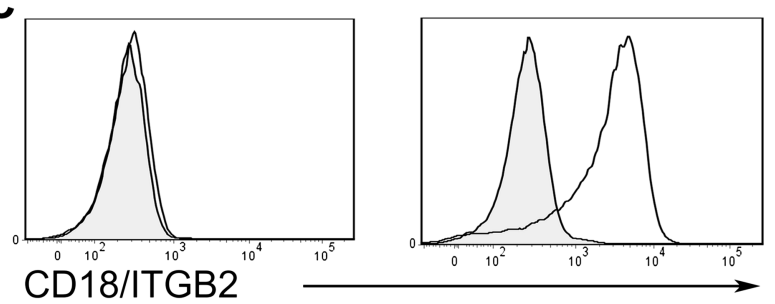

D

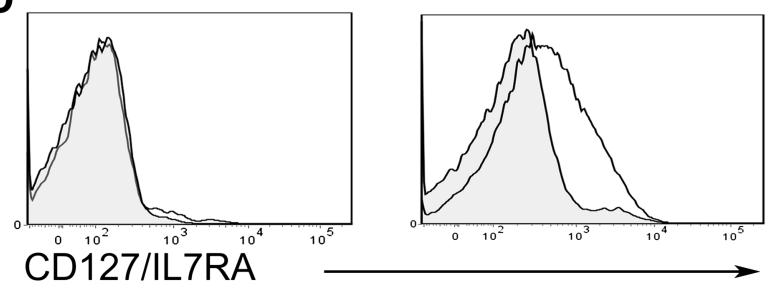

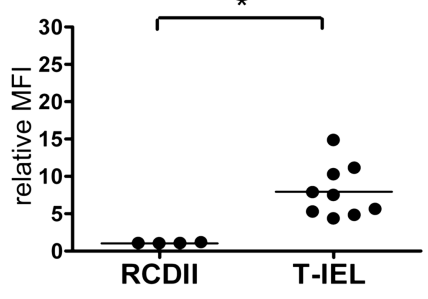
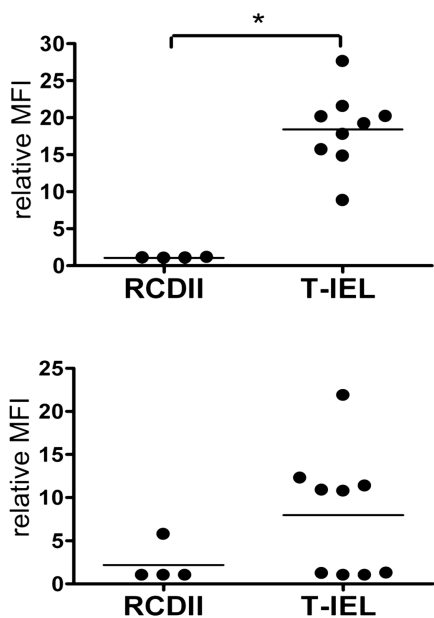

flow cytometric analysis of IELs from duodenal biopsies of children and adults without CD showed that cells with this phenotype were indeed present (figure $3 \mathrm{~A}$ ). These cells constituted on average $4 \%$ (range $0-8 \%, n=10$ ) of the $\mathrm{CD} 45^{+} \mathrm{SSC}^{\text {low }}$ population in adults without $\mathrm{CD}$ and were more abundant (average $13 \%$, range $4-32 \%, n=10$ ) in children without $\mathrm{CD}$ (figure $3 \mathrm{~B}$ ). In children with $\mathrm{CD}$, this subset formed on average $0.7 \%$ (range $0-2 \%, n=11$ ) of the $\mathrm{CD}_{4} 5^{+} \mathrm{SSC}^{\text {low }}$ population while this was on average $1.8 \%$ (range $0-10 \%, n=16$ ) in adults with $\mathrm{CD}$. Thus, $\mathrm{Lin}^{-} \mathrm{CD} 7^{+} \mathrm{CD} 127^{-} \mathrm{CD} 34^{-}$IELs are present in the duodenum of people without CD and in those with CD.

In contrast to the duodenum, few $\mathrm{Lin}^{-} \mathrm{CD} 7^{+} \mathrm{CD} 127^{-} \mathrm{CD} 34^{-}$ IELs were found in the ileum (average $0.3 \%, n=2$; data not shown) and colon (average $0.1 \%, n=3$; data not shown). Furthermore, $\mathrm{Lin}^{-} \mathrm{CD}^{+} \mathrm{CD} 127^{-} \mathrm{CD} 34^{-}$IELs were not detected in two fetal intestinal samples (data not shown). Most $\mathrm{CD}^{-} \mathrm{CD}^{+}$cells in the fetal intestinal samples were $\mathrm{CD}^{+} 6^{+}$or $\mathrm{CD} 127^{+}$cells (data not shown). In human thymic cell suspensions, $\mathrm{Lin}^{-} \mathrm{CD} 7^{+} \mathrm{CD} 127^{-} \mathrm{CD} 34^{-}$cells expressing $\mathrm{CD} 103$ constituted on average $0.1 \%$ (range $0.0-0.3 \%, n=4$ ) of $\mathrm{CD} 45^{+} \mathrm{SSC}^{\text {low }}$ thymocytes (figure $3 \mathrm{C}$ ). These findings indicate that the postnatal duodenum is the preferential intestinal site for $\mathrm{Lin}^{-} \mathrm{CD} 7^{+} \mathrm{CD} 127^{-} \mathrm{CD} 34^{-}$IELs, and suggest that this population may be thymus derived.

The classical definition of aberrant IELs in RCDII includes the presence of intracellular CD3 $\varepsilon$. Indeed, the large majority (average $88 \%$, range $66-99 \% \mathrm{n}=4$ ) of $\mathrm{Lin}^{-} \mathrm{CD} 7^{+} \mathrm{CD} 127^{-} \mathrm{CD} 34^{-}$ IELs in RCDII duodenal biopsies expressed CD3 intracellularly (figure 3D,E), while this was on average $51 \%$ (range 8-91, $\mathrm{n}=11$ ) in people with $\mathrm{CD}$ and $31 \%$ (range $27-37, \mathrm{n}=9$ ) in people without $\mathrm{CD}$ (figure $3 \mathrm{D}, \mathrm{E}$ ). On average $23 \%$ (range $11-37 \%$, $\mathrm{n}=3$ ) of $\mathrm{Lin}^{-} \mathrm{CD} 7^{+} \mathrm{CD} 127^{-} \mathrm{CD} 34^{-}$IELs in the thymus showed intracellular CD3 expression (figure 3D,E).

In conclusion, a sizeable fraction of the $\mathrm{Lin}^{-} \mathrm{CD} 7^{+}$

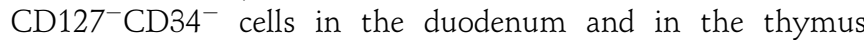
expressed intracellular CD3e.

\section{$\mathrm{Lin}^{-} \mathrm{CD7}^{+} \mathrm{CD}^{-27^{-} \mathrm{CD}^{-}} 4^{-}$form a subpopulation of $\mathrm{CD3}^{-} \mathrm{CD7}^{+}{ }^{\text {icCD3 }}{ }^{+}$cells}

As the diagnosis of RCDII and enteropathy-associated T-cell lymphoma (EATL) is made on the basis of the identification of a $\mathrm{CD}^{-} \mathrm{CD}^{+}{ }^{+} \mathrm{icDD}^{+}$cell population either by histological or flow cytometric means, ${ }^{6-837}$ we inverted our gating strategy to determine the specific phenotype of the $\mathrm{CD}^{-} \mathrm{CD}^{+}{ }^{\text {ic }} \mathrm{CD} 3^{+}$ population. Using this strategy we observed that in patients without RCD (patients with CD and those without CD) this duodenal $\mathrm{CD}^{-} \mathrm{CD}^{+}{ }^{\text {icCD}} 3^{+}$cell population was composed of four distinct populations: $\mathrm{CD}_{5} 6^{+} \mathrm{CD} 127^{-}, \mathrm{CD}^{+} 6^{+} \mathrm{CD} 127^{+}$, $\mathrm{CD}^{-} 6^{-} \mathrm{CD} 127^{-}$and $\mathrm{CD}^{-} 6^{-} \mathrm{CD} 127^{+}$(figure 4A). In patients with RCDII $(n=4)$ only two populations were observed: $\mathrm{CD}^{-} 6^{-} \mathrm{CD} 127^{-}$and $\mathrm{CD} 56^{-} \mathrm{CD} 127^{+}$cells (figure 4B). In the thymus the $\mathrm{CD}^{-} \mathrm{CD}^{+}{ }^{-} \mathrm{cCD} 3^{+}$cells predominantly expressed $\mathrm{CD}_{56}{ }^{+}$or were $\mathrm{CD} 6^{-} \mathrm{CD} 127^{-}$(figure $4 \mathrm{C}$ ). These findings revealed that the duodenal $\mathrm{CD}^{-} \mathrm{CD}^{+}{ }^{+} \mathrm{iCD}^{+}$IEL population is heterogeneous and that a subset of aberrant IELs in patients with RCDII biopsies express IL-7R (CD127). 
A
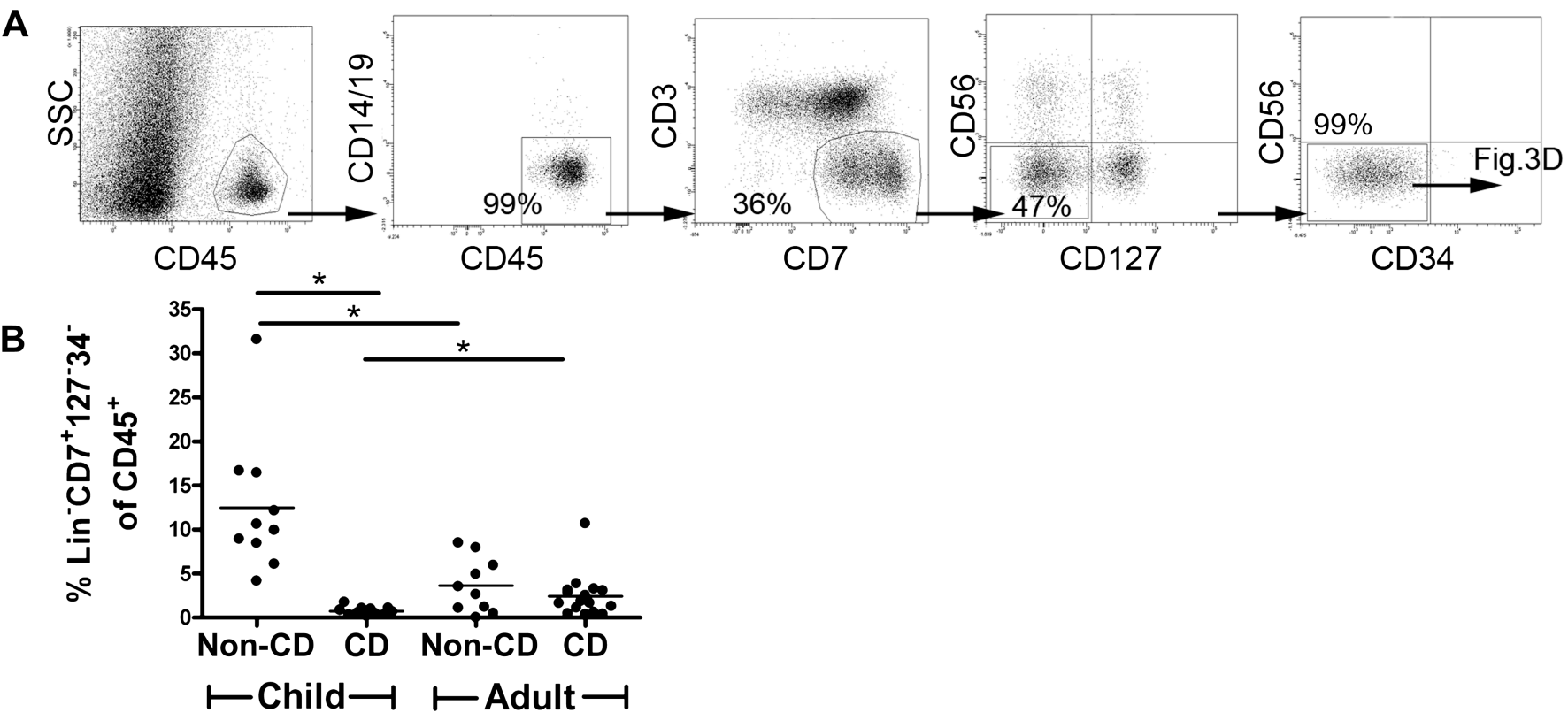

C

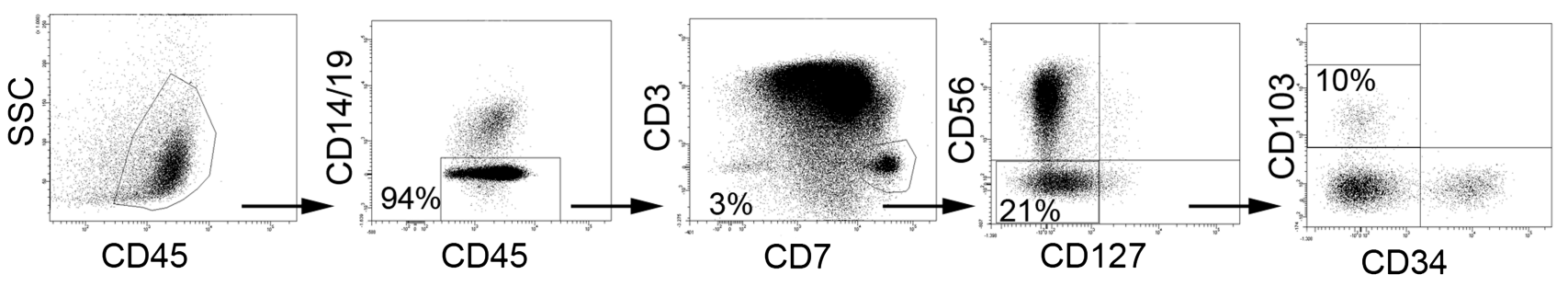

D
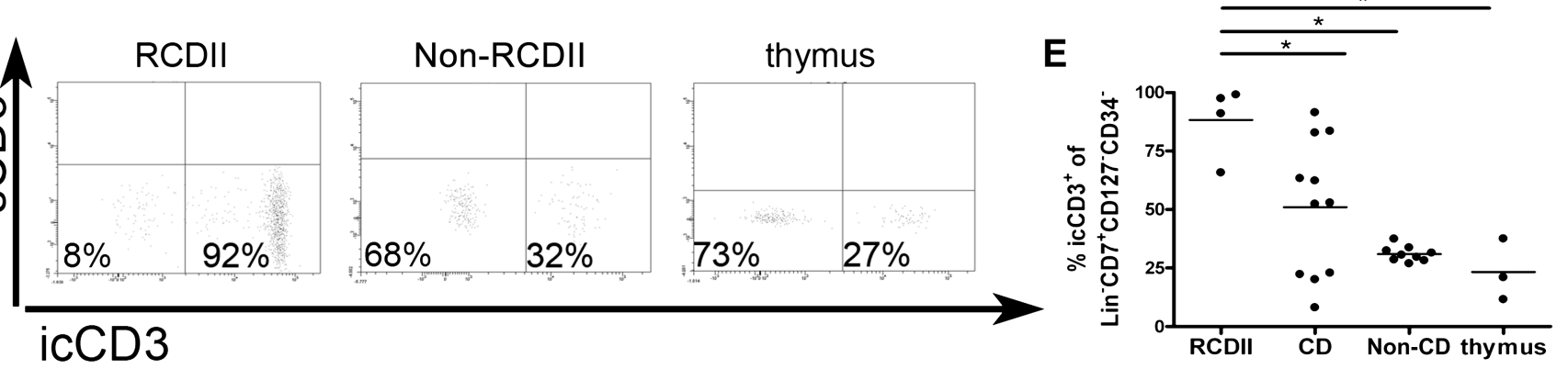

Figure $3 \mathrm{Lin}^{-} \mathrm{CD} 7^{+} \mathrm{CD} 127^{-} \mathrm{CD} 34^{-}$IELs are a physiological lymphocyte population in people with and without CD. (A) FACS analysis of cells isolated from the epithelium of duodenal biopsies from a child without CD. Each plot shows the cells gated in the previous plot with the calculated percentages from the previous gate. The experiment shown is qua gating and populations representative of adults without $C D(n=10)$ and children without $C D$ $(n=10)$. (B) Fraction of $\mathrm{Lin}^{-} \mathrm{CD} 7^{+} \mathrm{CD} 127^{-} \mathrm{CD} 34^{-}$IELs in duodenal biopsies expressed as a percentage of the CD45 ${ }^{+}$SSC low population. This graph summarises data from 11 children with CD (CD), 10 children without CD (no CD), 16 adults with CD (CD) and 10 adults without CD (no CD). (C) FACS analysis of a healthy thymus (8-month-old child) using the same gating strategy and calculations as described in A. Plots are representative of four donors. (D) Representative FACS plot depicts intracellular CD3 staining of $\mathrm{Lin}^{-} \mathrm{CD} 7^{+} \mathrm{CD} 127^{-} \mathrm{CD} 34^{-}$IELs in a patient with RCDII, an individual without RCD and a thymus sample. (E) Percentages of intracellular $C D 3^{+}$cells within Lin ${ }^{-} \mathrm{CD} 7^{+} \mathrm{CD} 127^{-} \mathrm{CD} 34^{-}$IELs in patients with RCDII ( $\left.n=4\right)$, patients with $C D(n=11)$, and those without $C D(n=9)$ and thymus samples $(n=3) .{ }^{*} p<0,05$ (unpaired Student $t$ test). CD, coeliac disease; IEL, intraepithelial lymphocyte; RCD, refractory coeliac disease; s, surface; ic, intracellular.

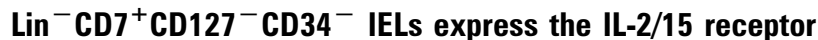 $\beta$ chain and proliferate in response to IL-15}

Expression of the cytokine IL-15 is elevated in the duodenum of patients with CD and RCD. ${ }^{3}$ As IL- 15 is critical for the survival and expansion of RCDII cell lines ${ }^{3}{ }^{38}$ we examined the expression of the IL-2/15 receptor $\beta$ chain (CD122) on IEL subsets from non-coeliac $(n=5)$, coeliac $(n=2)$ and RCDII $(n=1)$ duodenal biopsies (figure $5 \mathrm{~A}, \mathrm{~B}$ ). $\mathrm{Lin}^{-} \mathrm{CD} 7^{+} \mathrm{CD} 127^{-} \mathrm{CD} 34^{-}$IELs expressed CD122 (figure 5A). In fact, CD122 expression levels on these cells were higher than on NK cells, which are known to be IL-15 responsive. However, CD122 expression levels on $\mathrm{Lin}^{-} \mathrm{CD} 7^{+}$ $127^{+} 34^{-}$cells were lower than on NK cells and no CD122 was detected on T cells (figure 5B). CD122 expression by PBMC from the same patients showed a different pattern as $\mathrm{Lin}^{-} \mathrm{CD}^{+}$ $\mathrm{CD}^{2} 27^{-} \mathrm{CD} 34^{-}$cells in blood had a lower CD122 expression than NK cells, while T cells, like in biopsies, were negative for CD122 expression (figure 5C).

As $\mathrm{Lin}^{-} \mathrm{CD}^{+} \mathrm{CD} 127^{-} \mathrm{CD} 34^{-}$IELs expressed the IL-2/15 receptor $\beta$ chain (CD122) in the absence of the IL-2 receptor $\alpha$ chain (CD25, data not shown), they expressed a receptor for IL-15 but not a high-affinity IL-2 receptor. To test whether these cells were indeed IL-15 responsive, IELs released from paediatric non-celiac biopsies were incubated with IL-15 for 3 days. In the presence of IL-15, approximately $25 \%$ of 
Figure $4 \mathrm{CD}^{-} \mathrm{CD}^{+}{ }^{+} \mathrm{icD}^{+}$cells form a heterogeneous population. FACS analysis of $\mathrm{CD} 45^{+} \mathrm{SSC}^{\text {low }} \mathrm{CD} 14^{-} / \mathrm{CD} 19^{-}$ intraepithelial cells isolated from duodenal biopsies of $(A)$ people without RCD (no CD: $n=9, C D: n=11$ ), (B) patients with RCDII $(n=4)$ and $(C)$ healthy thymuses $(n=3)$.

Representative dot plots are shown on the left; each plot depicts the cells gated in the previous plot. The graphs on the right summarise the results: the average $( \pm S D)$ size of each of four subsets of $\mathrm{CD}^{-} \mathrm{CD}^{+}{ }^{+}$icCD $^{+}$cells is shown, based on the presence or absence of CD127 and CD56. RCD, refractory coeliac disease.
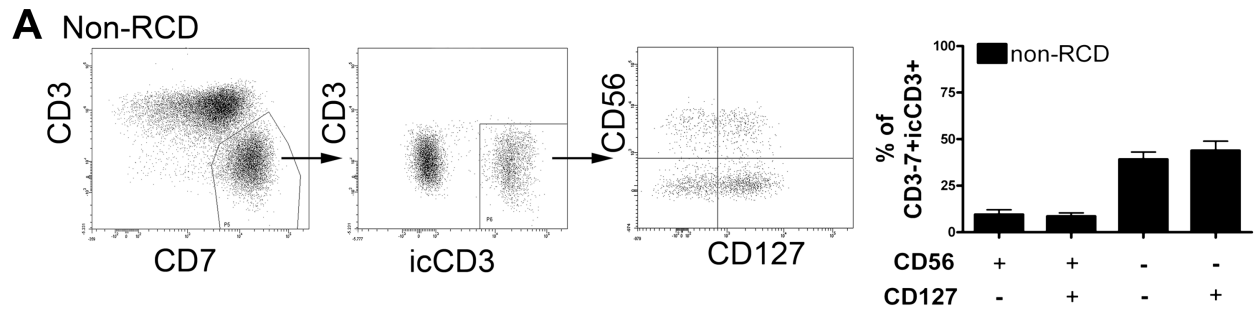

B RCDII
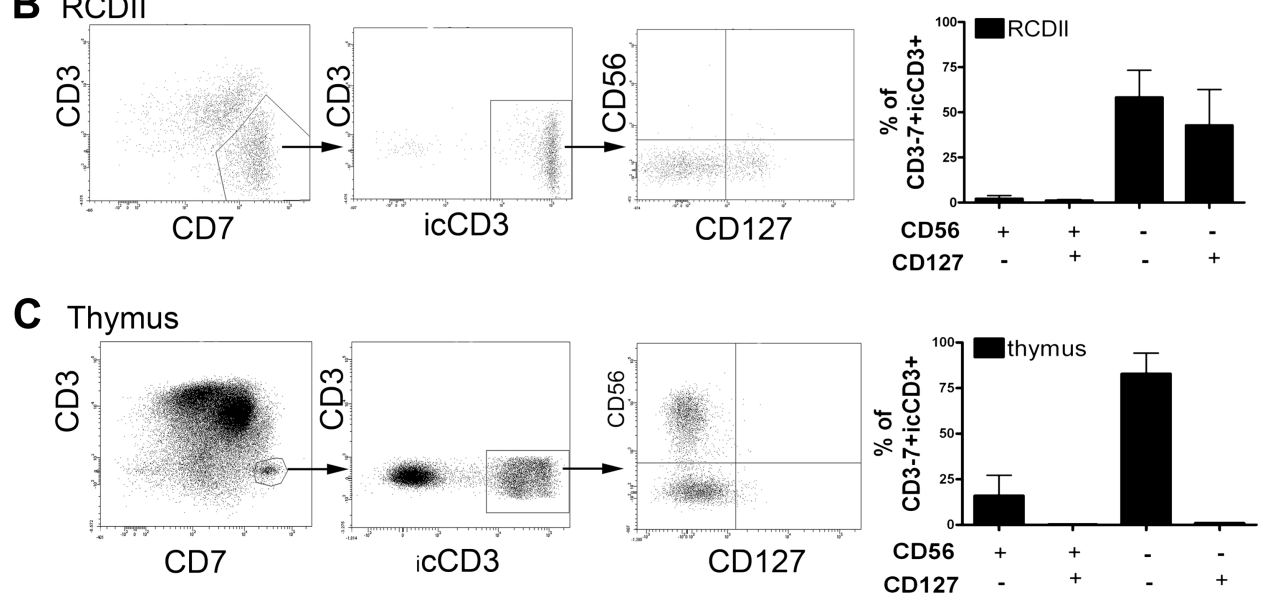

$\mathrm{Lin}^{-} \mathrm{CD} 7^{+} \mathrm{CD} 127^{-} \mathrm{CD} 34^{-}$IELs were positive for the nuclear proliferation marker $\mathrm{Ki}-67$, compared with approximately $5 \%$ in the absence of IL-15 (figure 6). A similar picture was observed for the NK cells among the IELs (figure 6), which also expressed CD122 (figure 5). In contrast, no increase in $\mathrm{Ki}-67^{+}$cell numbers was detectable for $\mathrm{Lin}^{-} \mathrm{CD}^{+} 127^{+} 34^{-}$cells and $\mathrm{CD}^{+} \mathrm{T}$ cells (figure 6), which did not express CD122 (figure 5). Together, these results indicate that duodenal $\mathrm{Lin}^{-} \mathrm{CD} 7^{+} \mathrm{CD} 127^{-} \mathrm{CD} 34^{-}$
IELs proliferate in response to IL-15 via the IL-2/15 receptor $\beta$ chain.

\section{DISCUSSION}

In this study we performed an in-depth analysis of aberrant RCDII lines isolated from biopsies of patients with RCDII to uncover the cellular origin of these aberrant cells. Compared with $\mathrm{TCR}^{+} \mathrm{CD}^{+}$IELs, these RCDII lines expressed more
Figure 5 CD122 (IL2/IL-15R $\beta$ ) expression on $\mathrm{T}$, $\mathrm{Lin}^{-} \mathrm{CD}^{+}$ CD127- ${ }^{-} D 34^{-}$IELs, Lin $^{-} \mathrm{CD}^{+}$ $\mathrm{CD} 127^{+} \mathrm{CD}^{-} 4^{-}$and NK cells. (A) Representative experiment of the CD122 expression of IEL subsets of a child without CD. The MFI of surface CD122 expression of $\mathrm{T}_{\text {cells }}\left(\mathrm{CD}^{+}{ }^{+}\right.$), $\mathrm{Lin}^{-} \mathrm{CD}^{+} \mathrm{CD}^{-} 27^{-} \mathrm{CD} 34^{-}$IELs, $\mathrm{Lin}^{-} \mathrm{CD}^{+} \mathrm{CD}^{2} 27^{+} \mathrm{CD}^{-} 4^{-}$IEL and NK cells (CD3 ${ }^{-} \mathrm{CD}^{+} 6^{+} \mathrm{CD}_{127^{+/-}}$) is depicted between square brackets. The CD122 expression is shown on the $\mathrm{x}$-axis and the cell count on the $\mathrm{y}$-axis. All IELs depicted here are $\mathrm{CD} 45^{+} \mathrm{SSC}^{\text {low }}$ $\mathrm{CD}^{-} 4^{-} \mathrm{CD}_{19}^{-} \mathrm{CD}^{+}{ }^{+} \mathrm{CD} 34^{-}$. (B) $\mathrm{CD} 122$ MFI expression of IEL subsets. Expression of CD3, CD56 and CD127 is used to differentiate the subpopulations as explained for $(\mathrm{A})$ within $\mathrm{CD} 45^{+}$ $\mathrm{SSC}^{\text {low }} \mathrm{CD}^{-} 4^{-} \mathrm{CD}^{-} 9^{-} \mathrm{CD7}^{+} \mathrm{CD}^{-} 4^{-}$cells from biopsies. (C) CD122 MFI expression of PBMC subsets. Expression of CD3, 56 and CD127 is used to differentiate the subpopulations within $\mathrm{CD} 45^{+} \mathrm{SSC}^{\mathrm{low}} \mathrm{CD} 14^{-} \mathrm{CD} 19$ $\mathrm{CD}^{+}{ }^{+} \mathrm{CD} 34^{-}$cells in PBMCs from the same donors as in (B). (B) and (C) summarise data from eight donors
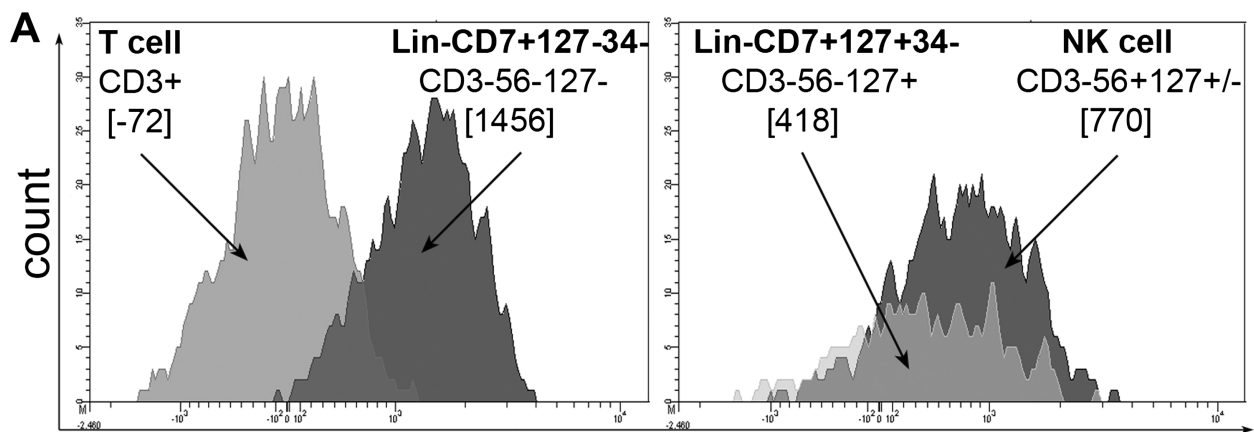

CD122

B IEL subsets

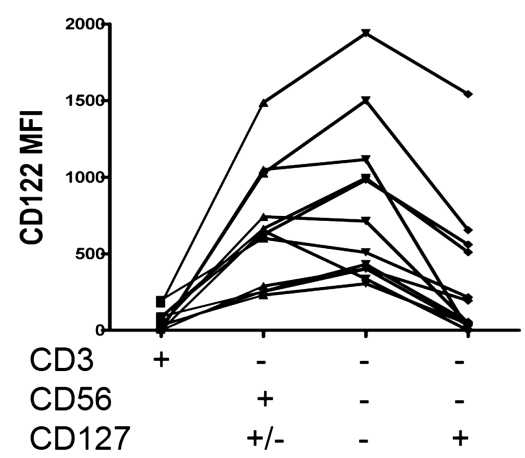

C

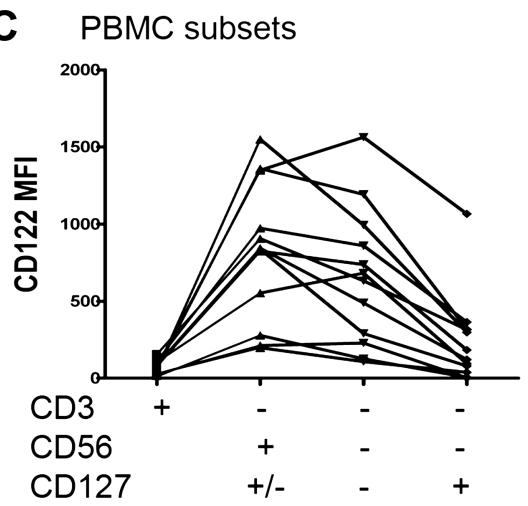

(no $C D, n=5 ; C D, n=2 ; R C D I I, n=1$ ). Lines connect data from individual donors. IEL, intraepithelial lymphocyte; MFI, mean fluorescence intensity; NK, natural killer; PBMC, peripheral blood mononuclear cell; RCDII, refractory coeliac disease type II. 
Figure $6 \mathrm{Lin}^{-} \mathrm{CD} 7^{+} \mathrm{CD} 127^{-} \mathrm{CD} 34^{-}$ IELs proliferate in response to IL-15. IELs released from the biopsy of a child without CD were incubated for 3 days with $10 \mathrm{ng} / \mathrm{ml} \mathrm{IL-15}$ and subsequently analysed by flow cytometry. Intracellular Ki-67 staining upon incubation in the absence (left) or presence (right) of IL-15 is shown for T cells $\left(\mathrm{CD}^{+}\right)$, NK cells

$\left(\mathrm{CD} 3^{-} \mathrm{CD}^{+} 6^{+} \mathrm{CD} 127^{+/-}\right.$),

$\mathrm{Lin}^{-} \mathrm{CD}^{+}{ }^{+} \mathrm{CD} 127^{-} \mathrm{CD} 34^{-}$cells and $\mathrm{Lin}^{-} \mathrm{CD}^{+}{ }^{+} \mathrm{CD} 127^{+} \mathrm{CD} 34^{-}$cells among IELs, gated as in figure 5. One experiment is shown, representative of two. IEL, intraepithelial lymphocyte; IL, interleukin; NK, natural killer.
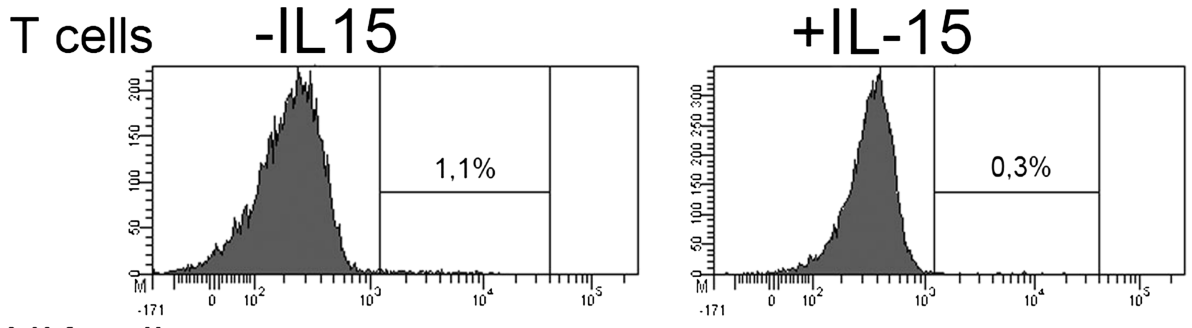

NK cells
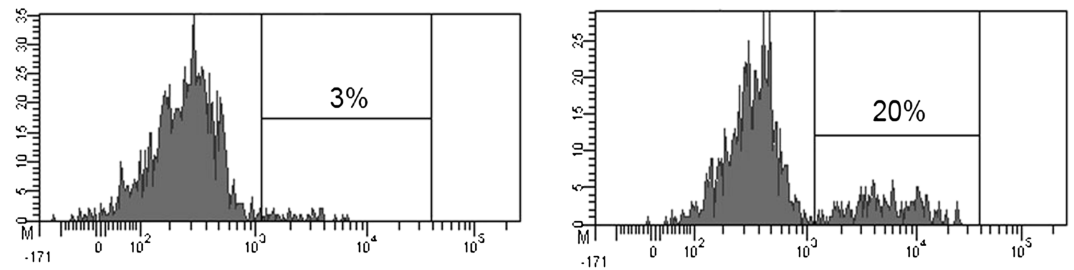

Lin-CD7+CD127-CD34-
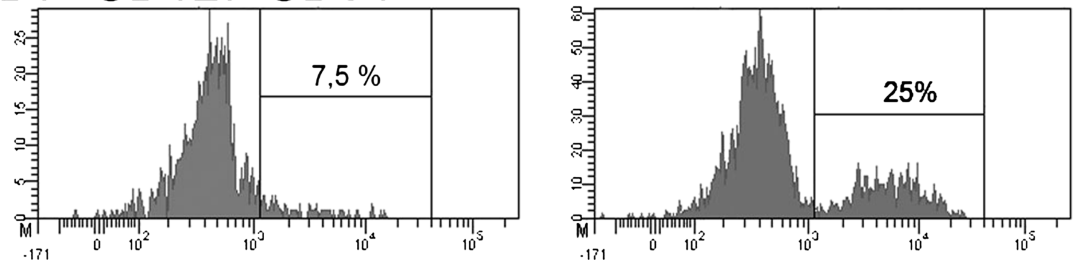

Lin-CD7+CD127+CD34-

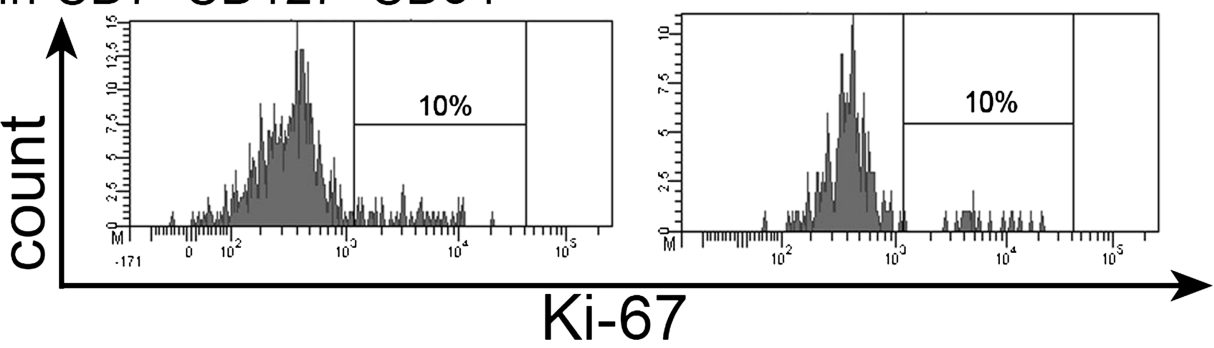

NK-cell-associated transcripts, including KIR. The RCDII lines lacked surface expression of lineage markers, as well as the expression of CD127 and CD34 ( $\left.\mathrm{Lin}^{-} \mathrm{CD} 7^{+} \mathrm{CD} 127^{-} \mathrm{CD} 34^{-} \mathrm{IELs}\right)$, but highly expressed the IL-15/2R $\beta$ chain (CD122). Cells with this phenotype were also found in duodenal biopsies of people without $\mathrm{CD}$ and in the healthy thymus, but were less frequent in ileal and colonic epithelium and undetectable in the fetal intestine.

Characteristic for aberrant cells in RCDII, $\mathrm{Lin}^{-} \mathrm{CD} 7^{+}$ CD $127^{-} \mathrm{CD}^{-} 4^{-}$IELs do not match any previously described physiological (non-pathological) IEL subset. In the duodenum of people without $\mathrm{CD}$, particularly children, these cells constituted up to $30 \%$ of $\mathrm{CD} 45^{+} \mathrm{SSC}^{\text {low }}$ cells. Strikingly, these cells were 18-fold more frequent in children without CD compared with children with $\mathrm{CD}$. This difference in numbers between people with $\mathrm{CD}$ and those without $\mathrm{CD}$ mirrors previous studies regarding the $\mathrm{CD}^{-} \mathrm{CD}^{+}$population. ${ }^{12}{ }^{13}$ Even after correction for the twofold to fourfold increase in total IEL numbers in active $\mathrm{CD},{ }^{39-42}$ absolute numbers of $\mathrm{Lin}^{-} \mathrm{CD}^{+} \mathrm{CD} 127^{-} \mathrm{CD} 34^{-}$IELs remain reduced in children with $\mathrm{CD}$ compared with those without CD.

$\mathrm{Lin}^{-} \mathrm{CD} 7^{+} \mathrm{CD} 127^{-} \mathrm{CD} 34^{-}$cells that expressed the guthoming receptor $\mathrm{CD}_{103}{ }^{43}$ were also present in the human thymus. This may point to a thymic origin of these cells in the gastrointestinal epithelium. The low frequency of these cells in the ileum and colon compared with the duodenum suggests that the latter would be a preferential site for homing of such thymic emigrants. Strikingly, Lin $^{-} \mathrm{CD} 7^{+} \mathrm{CD} 127^{-} \mathrm{CD} 34^{-}$IELs were not detected in the fetal intestine. Therefore, if these cells in the duodenum are indeed of thymic origin, this suggests migration from the thymus later in life. Together, the data fit a scenario in which the frequencies of these intestinal cells peak when the thymus is highly active, that is, during the first postnatal decade.

Data from this study support and extend further studies focusing on the intestinal $\mathrm{CD}^{-} \mathrm{CD}^{+}$cell population, which included immature Tcells and NK cells. ${ }^{12-1844}$ Using multicolour flow cytometry we could further define the different subpopulations in this heterogeneous $\mathrm{CD}^{-} \mathrm{CD}^{+}$cell population. Additional markers such as icCD3, CD56, CD127 and CD34 proved that $\mathrm{Lin}^{-} \mathrm{CD}^{+} \mathrm{CD} 127^{-} \mathrm{CD} 34^{-}$IELs are distinct from Tcells, NK, $\mathrm{LTi}$ and early $\mathrm{CD} 34^{+}$precursor cells. It is tempting to speculate that the $\mathrm{Lin}^{-} \mathrm{CD} 7^{+} \mathrm{CD} 127^{-} \mathrm{CD} 34^{-}$IELs represent intermediate NK/T-lymphocyte precursors that undergo extrathymic differentiation, as was shown for other intestinal IEL subsets. ${ }^{18}{ }^{45-47}$

In fetal thymic organ cultures, a minority of the $\mathrm{CD}^{-} \mathrm{CD} 7$ cells developed into T cells. ${ }^{14}$ In line with a pre T cell phenotype, RCDII cell lines P1, P2 and P4 (but not P3) contained partial TCR rearrangements. ${ }^{29}$ Lin $^{-} \mathrm{CD}^{+} \mathrm{CD} 127^{-} \mathrm{CD} 34^{-}$IELs may therefore be identical to the immature T cells contained within the $\mathrm{CD}^{-} \mathrm{CD}^{+}$cell population. However, the RCDII lines and duodenal $\mathrm{Lin}^{-} \mathrm{CD} 7^{+} \mathrm{CD} 127^{-} \mathrm{CD} 34^{-}$IELs in vivo expressed the IL-2/15 receptor $\beta$ chain (CD122) which could be detected on $\mathrm{CD}^{-} \mathrm{CD} 7$ cells in the epithelium, ${ }^{13}$ but is normally found on NK-cell but not T-cell precursors. ${ }^{33}$ Thus it will be important to 
test the ability of $\mathrm{Lin}^{-} \mathrm{CD} 7^{+} \mathrm{CD} 127^{-} \mathrm{CD} 34^{-}$IELs to differentiate into Tor NK cells in in vitro differentiation systems. This will be the subject of further investigation.

The presence of copious amounts of IL-15 in RCD is likely to contribute to the expansion and survival of (aberrant) IELs. $^{3}{ }^{9}{ }^{38}$ In CD it induces NK programming of TCR $\alpha \beta^{+} \mathrm{CD} 8^{+}$ IELs. ${ }^{30} 314849 \mathrm{Lin}^{-} \mathrm{CD} 7^{+} \mathrm{CD} 127^{-} \mathrm{CD} 34^{-}$IELs, regardless of the disease status, expressed the IL-2/15 receptor $\beta$ chain in the absence of the IL-2 receptor $\alpha$ chain. In line with this finding, in children without $\mathrm{CD} \mathrm{Lin}^{-} \mathrm{CD}^{+} \mathrm{CD}^{-} 27^{-} \mathrm{CD} 34^{-}$IELs proliferated in response to IL-15, providing a potential link between the upregulation of IL-15 and the outgrowth of cells with a

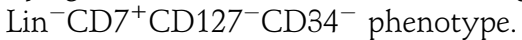

Microarray analysis showed that, compared with regular T-IEL lines, the RCDII lines expressed lower levels of several T-cell-associated genes, but higher levels of NK-cell-associated genes. Notably, the RCDII lines each expressed a unique combination of KIR, normally expressed after the appearance of NKp46 (present on P3 only) and CD56 (present on a small fraction of P3 only) in NK-cell development or well after the completion of TCR rearrangements in T cells. It is therefore conceivable that IL-15, a critical cytokine in NK-cell development, induces the expansion and survival, and the acquisition of NK-cell receptors on aberrant IELs in RCDII.

Quantification of the $\mathrm{CD}^{-} \mathrm{CD}^{+}{ }_{\mathrm{icCD}}{ }^{+}$population provides the basis for diagnosis of RCDII. ${ }^{6-8} 37$ Our results demonstrate that in people without $\mathrm{CD}$, and in patients with $\mathrm{CD}$, the $\mathrm{CD}^{-} \mathrm{CD}^{+}{ }^{+} \mathrm{icCD} 3$ cells are heterogeneous and composed of four subsets based on the expression of CD127 and CD56, one of which displays the $\mathrm{Lin}^{-} \mathrm{CD} 7^{+} \mathrm{CD} 127^{-} \mathrm{CD} 34^{-}$IEL phenotype. In patients with RCDII, CD56 ${ }^{-} \mathrm{CD} 127^{-}$and $\mathrm{CD} 6^{-} \mathrm{CD} 127^{+}$subsets were observed, which fits the observation that lymphomas arising in patients with RCDII are usually $\mathrm{CD} 6^{-}{ }^{50}$ This diverse phenotype of $\mathrm{CD}^{-} \mathrm{CD}^{+}{ }^{\mathrm{icCD}} 3^{+}$cells in vivo, however, was mirrored in the RCDII cell lines, as a sizeable fraction of P4 expressed CD127 and a minor fraction of P3 expressed CD56. Proliferation and a (pre)malignant transformation of aberrant IELs in RCDII and EATL could therefore take place at different time points of cellular development, potentially ranging from pre $\mathrm{T} / \mathrm{NK}$ cells to nearly mature T cells with near-complete TCR rearrangements.

In conclusion, our studies indicate that 'aberrant' IELs in RCDII may be derived from a preexistent $\mathrm{Lin}^{-} \mathrm{CD} 7^{+} \mathrm{CD} 127^{-}$ CD34- IEL population present in the duodenum of people with and without CD.

Acknowledgements We thank Drs C. Vilches, D. Pende and C. Retiere for providing KIR specific antibodies and R. Ruslan, R. Versteegh, K. van der Ploeg, S. de Boo, M. Romera Hernandez and H. Binh Nguyen for experimental support.

Contributors FS and JMLT acquired the data, analysed and interpreted the data and drafted the manuscript. YL analysed data. AT, YK-W and RJL acquired data and gave technical support. HWV, MLM, FJS, MWJS and CJM gave material support. FJS, TC and AWL acquired data and revised the manuscript for important intellectual content. FK obtained funding and with JvB drafted the manuscript, implemented the study concept, design and study supervision.

Funding This research received a specific grant from the Coeliac Disease Consortium (grant number: BSIK03009), Centre for Medical Systems Biology within the framework of the Netherlands Genomics Initiative/Netherlands Organization for Scientific Research and by the Dutch Digestive Disease Foundation (W0 06-21,0515), Landsteiner Foundation for Blood Transfusion Research, Innovational Research Incentives Scheme Vidi grant (grant number: 91710377).

Competing interests None

Patient consent Obtained.

Ethics approval Local ethical guidelines of the VU Medical Center in Amsterdam (adult duodenal biopsies), the Leiden University Medical Center (paediatric duodenal biopsies), the Erasmus MC in Rotterdam (fetal intestine, thymuses) in accordance with the declaration of Helsinki.

Provenance and peer review Not commissioned; externally peer reviewed.

Data sharing statement The complete microarray data from this study are available via the GEO website: http://www.ncbi.nlm.nih.gov/geo/. The GEO series record is GSE33078.

\section{REFERENCES}

1. Lundin KE, Scott $H$, Hansen T, et al. Gliadin-specific, HLA-DQ(alpha $1{ }^{*} 0501$, beta $1^{*} 0201$ ) restricted T cells isolated from the small intestinal mucosa of celiac disease patients. J Exp Med 1993;178:187-96.

2. Kutlu T, Brousse N, Rambaud C, et al. Numbers of T cell receptor (TCR) alpha beta+ but not of TcR gamma delta + intraepithelial lymphocytes correlate with the grade of villous atrophy in coeliac patients on a long term normal diet. Gut 1993;34:208-14.

3. Mention JJ, Ben AM, Begue B, et al. Interleukin 15: a key to disrupted intraepithelial lymphocyte homeostasis and lymphomagenesis in celiac disease. Gastroenterology 2003;125:730-45.

4. Di Sabatino A, Ciccocioppo R, Cupelli F, et al. Epithelium derived interleukin 15 regulates intraepithelial lymphocyte Th1 cytokine production, cytotoxicity, and survival in coeliac disease. Gut 2006;55:469-77.

5. Al-Toma A, Verbeek WH, Hadithi $M$, et al. Survival in refractory coeliac disease and enteropathy-associated T-cell lymphoma: retrospective evaluation of single-centre experience. Gut 2007:56:1373-8.

6. Verbeek WH, Goerres MS, von Blomberg BM, et al. Flow cytometric determination of aberrant intra-epithelial lymphocytes predicts T-cell lymphoma development more accurately than T-cell clonality analysis in refractory celiac disease. Clin Immunol 2008:126:48-56

7. Cellier C, Patey N, Mauvieux L, et al. Abnormal intestinal intraepithelial lymphocytes in refractory sprue. Gastroenterology 1998:114:471-81.

8. Malamut G, Afchain P, Verkarre V, et al. Presentation and long-term follow-up of refractory celiac disease: comparison of type I with type II. Gastroenterology 2009:136:81-90.

9. Tjon JM, Verbeek WH, Kooy-Winkelaar YM, et al. Defective synthesis or association of T-cell receptor chains underlies loss of surface T-cell receptor-CD3 expression in enteropathy-associated T-cell lymphoma. Blood 2008;112:5103-10.

10. Lanier LL, Chang C, Spits H, et al. Expression of cytoplasmic CD3 epsilon proteins in activated human adult natural killer (NK) cells and CD3 gamma, delta, epsilon complexes in fetal NK cells. Implications for the relationship of NK and T lymphocytes. J Immunol 1992;149:1876-80.

11. De Smedt M, Taghon T, Van de Walle I, et al. Notch signaling induces cytoplasmic CD3 epsilon expression in human differentiating NK cells. Blood 2007;110:2696-703.

12. Spencer J, MacDonald TI. Diss TC et al. Changes in intraepithelial lymphocyte subpopulations in celiac-disease and enteropathy associated T-cell lymphoma (malignant histiocytosis of the intestine). Gut 1989;30:339-46.

13. Eiras $\mathbf{P}$, Leon $\mathbf{F}$, Camarero $\mathbf{C}$, et al. Intestinal intraepithelial lymphocytes contain a CD3 $(-) \operatorname{CD} 7(+)$ subset expressing natural killer markers and a singular pattern of adhesion molecules. Scand J Immunol 2000:52:1-6.

14. Gunther U, Holloway JA, Gordon JN, et al. Phenotypic characterization of CD3-7+ cells in developing human intestine and an analysis of their ability to differentiate into T cells. J Immunol 2005:174:5414-22.

15. Jarry A, Cerf-Bensussan N, Brousse N, et al. Subsets of CD3+ (T cell receptor alpha/beta or gamma/delta) and CD3- lymphocytes isolated from normal human gut epithelium display phenotypical features different from their counterparts in peripheral blood. Eur J Immunol 1990;20:1097-103.

16. Lundqvist C, Baranov V, Hammarstrom S, et al. Intra-epithelial lymphocytes. Evidence for regional specialization and extrathymic T cell maturation in the human gut epithelium. Int Immunol 1995;7:1473-87.

17. Leon F, Roldan E, Sanchez L, et al. Human small-intestinal epithelium contains functional natural killer lymphocytes. Gastroenterology 2003;125:345-56.

18. Williams AM, Bland PW, Phillips AC, et al. Intestinal alpha beta T cells differentiate and rearrange antigen receptor genes in situ in the human infant. $J$ Immunol 2004;173:7190-9.

19. Dik WA, Pike-Overzet K, Weerkamp F, et al. New insights on human T cell development by quantitative $T$ cell receptor gene rearrangement studies and gene expression profiling. J Exp Med 2005;201:1715-23.

20. Van Damme N, Baeten D, De Vos M, et al. Chemical agents and enzymes used for the extraction of gut lymphocytes influence flow cytometric detection of $T$ cell surface markers. J Immunol Methods 2000;236:27-35

21. David G, Morvan M, Gagne K, et al. Discrimination between the main activating and inhibitory killer cell immunoglobulin-like receptor positive natural killer cell subsets using newly characterized monoclonal antibodies. Immunology 2009:128:172-84.

22. Pende D, Biassoni $R$, Cantoni $C$, et al. The natural killer cell receptor specific for HLA-A allotypes: a novel member of the p58/p70 family of inhibitory receptors that is characterized by three immunoglobulin-like domains and is expressed as a $140-\mathrm{kD}$ disulphide-linked dimer. J Exp Med 1996;184:505-18.

23. Estefania E, Flores R, Gomez-Lozano N, et al. Human KIR2DL5 is an inhibitory receptor expressed on the surface of NK and T Iymphocyte subsets. J Immunol 2007;178:4402-10. 
24. Dunning MJ, Smith ML, Ritchie ME, et al. beadarray: $\mathrm{R}$ classes and methods for Illumina bead-based data. Bioinformatics 2007;23:2183-4.

25. Smyth GK. Linear models and empirical Bayes methods for assessing differential expression in microarray experiments. Stat Appl Genet Mol Biol 2004;3:Article3.

26. Caraux A, Kim N, Bell SE, et al. Phospholipase C-gamma 2 is essential for NK cell cytotoxicity and innate immunity to malignant and virally infected cells. Blood 2006;107:994-1002

27. Morra M, Lu J, Poy F, et al. Structural basis for the interaction of the free SH2 domain EAT-2 with SLAM receptors in hematopoietic cells. EMBO $J$ 2001;20:5840-52.

28. Betser-Cohen G, Mizrahi S, Elboim M, et al. The association of MHC class I proteins with the 2B4 receptor inhibits self-killing of human NK cells. J Immunol 2010;184:2761-8

29. Tack GJ, van Wanrooij RLJ, Langerak AW, et al. Origin and immunophenotype of aberrant IEL in RCDII patients. Mol Immunol 2012;50:262-70.

30. Hue S, Mention JJ, Monteiro RC, et al. A direct role for NKG2D/MICA interaction in villous atrophy during celiac disease. Immunity 2004:21:367-77.

31. Meresse B, Curran SA, Ciszewski $\mathbf{C}$, et al. Reprogramming of CTLs into natural killerlike cells in celiac disease. J Exp Med 2006;203:1343-55.

32. Tjon JM, Kooy-Winkelaar YM, Tack GJ, et al. DNAM-1 mediates epithelial cellspecific cytotoxicity of aberrant intraepithelial lymphocyte lines from refractory celiac disease type II patients. J Immunol 2011;186:6304-12.

33. Blom B, Spits H. Development of human lymphoid cells. Annu Rev Immunol 2006;24:287-320.

34. Freud AG, Caligiuri MA. Human natural killer cell development. Immunol Rev 2006:214:56-72.

35. Cupedo T, Crellin NK, Papazian N, et al. Human fetal lymphoid tissue-inducer cells are interleukin 17-producing precursors to RORC+ CD127+ natural killer-like cells. Nat Immunol 2009;10:66-74.

36. Vivier E, Spits H, Cupedo T. Interleukin-22-producing innate immune cells: new players in mucosal immunity and tissue repair? Nat Rev Immunol 2009;9:229-34

37. Cellier C, Delabesse E, Helmer C, et al. Refractory sprue, coeliac disease, and enteropathy-associated T-cell lymphoma. French Coeliac Disease Study Group. Lancet 2000;356:203-8.
38. Malamut G, El MR, Montcuquet N, et al. IL-15 triggers an antiapoptotic pathway in human intraepithelial lymphocytes that is a potential new target in celiac diseaseassociated inflammation and lymphomagenesis. J Clin Invest 2010;120:2131-43.

39. Spencer J, Isaacson PG, Macdonald TT, et al. Gamma-delta T-cells and the diagnosis of celiac-disease. Clin Exp Immunol 1991;85:109-13.

40. Spencer J, Isaacson PG, Diss TC, et al. Expression of disulfide-linked and nondisulfide-linked forms of the T-cell receptor-gamma-delta heterodimer in human intestinal intraepithelial lymphocytes. Eur J Immunol 1989;19:1335-8.

41. Holmes GKT, Asquith P. Stokes PL, et al. Cellular infiltrate of jejunal biopsies in adult celiac-disease in relation to gluten withdrawal. Gut 1974;15:278-83.

42. Salmi TT, Collin P, Reunala T, et al. Diagnostic methods beyond conventional histology in coeliac disease diagnosis. Dig Liver Dis 2010;42:28-32.

43. Gorfu G, Rivera-Nieves J, Ley K. Role of beta(7) integrins in intestinal lymphocyte homing and retention. Curr Mol Med 2009;9:836-50.

44. Camarero C, Eiras P, Asensio A, et al. Intraepithelial lymphocytes and coeliac disease: permanent changes in $\mathrm{CD} 3-/ \mathrm{CD} 7+$ and $\mathrm{T}$ cell receptor gammadelta subsets studied by flow cytometry. Acta Paediatr 2000:89:285-90.

45. Lynch S, Kelleher D, Mcmanus R, et al. Rag1 and Rag2 expression in human intestinal epithelium-evidence of extrathymic T-cell differentiation. Eur J Immunol 1995;25:1143-7.

46. Howie D, Spencer J, DeLord D, et al. Extrathymic T cell differentiation in the human intestine early in life. J Immunol 1998;161:5862-72.

47. Bas A, Hammarstrom SG, Hammarstrom ML. Extrathymic TCR gene rearrangement in human small intestine: identification of new splice forms of recombination activating gene-1 mRNA with selective tissue expression. J Immunol 2003:171:3359-71

48. Meresse B, Chen ZG, Ciszewski C, et al. Coordinated induction by IL15 of a TCRindependent NKG2D signaling pathway converts CTL into lymphokine-activated kille cells in celiac disease. Immunity 2004;21:357-66.

49. Jabri B, De Serre NPM, Cellier C, et al. Selective expansion of intraepithelial lymphocytes expressing the HLA-E-specific natural killer receptor CD94 in celiac disease. Gastroenterology 2000;118:867-79.

50. Deleeuw RJ, Zettl A, Klinker E, et al. Whole-genome analysis and HLA genotyping of enteropathy-type T-cell lymphoma reveals 2 distinct lymphoma subtypes. Gastroenterology 2007;132:1902-11. 